\title{
THE CORRECTION OF THE CONSEQUENCES OF THE EXPERIMENTAL PROSTATITIS BY NANOPARTICLES OF ORTHOVANADATES OF THE RARE-EARTH ELEMENTS*
}

\author{
Chystiakova E. Ye. ${ }^{1}$, Smolienko N. P. ${ }^{1}$, Bielkina I. O. ${ }^{1}$, Velychko N. F. ${ }^{1}$, \\ Korenieva Ye. M. ${ }^{1}$, Boiko M. O. ${ }^{1}$, Kustova S. P. ${ }^{1}$, Klochkov V. K. ${ }^{2}$, \\ Bondarenko V. O. ${ }^{1}$, Karpenko N. O. ${ }^{1}$ \\ ${ }^{1}$ SI "V. Danilevsky Institute for Endocrine Pathology Problems of the NAMS of Ukraine», \\ Kharkiv, Ukraine \\ ${ }^{2}$ SI "Institute for Scintillation Materials of NAS of Ukraine, Kharkiv, Ukraine» \\ reproduk@ipep.com.ua
}

According to the epidemiological researches, up to $45 \%$ of able-bodied men in Ukraine are suffering from the chronic prostatitis (CP), at that in $40 \%$ cases CP may causes men's infertility [1]. The treatment of patient with CP remains the difficult medical problem that conditions the actuality of researching and developing of new prostate protectors.

The elaboration of the entirely new drugs is the priority for professionals [2]. Thus, it is well known that changes of the physical properties of substances in a form of nanoparticles (NP) naturally lead to the changes of their biological effects [3, 4]. The small sizes of nanoparticles $(1 \mu \mathrm{m}-100 \mathrm{~nm})$ and variety of their shapes (dot-shaped, spherical, grains, nanorods etc.) promote to binding with nucleic acids and proteins, insertion into cells membranes and changing of biostructures functions [4-7]. The term «form-factor» is referred to combination of sizes and shapes parameters of nanoparticles. It has been experimentally detected that using of NP based on oxides of rare-earth elements may positively influences the reproductive function and demonstrates antioxidative properties $[6,7]$.

Therefore, the purpose of this work was to investigate the influence of rare-earth elements' nanoparticles of different form-factor on the correction of pathological condition of endocrine and spermatogenic function of the testicles caused by chronic experimental prostatitis.

* The investigation has been fulfilled according to the scientific cooperation agreement between SI «V. Danilevsky Institute for Endocrine Pathology Problems of the NAMS of Ukraine» and the Department for nonstructural materials of the Institute for Scintillation Materials of NAS of Ukraine (of 07.02.2018) and under the research theme of SI «V. Danilevsky Institute for Endocrine Pathology Problems of the NAMS of Ukraine» «The correction of the reproductive function disturbances under experimental modeling of prostatitis in rats by nanoparticles based on the oxides of rare-earth elements» (state registration № 0117U00788).

The research funding institution is the NAMS of Ukraine.

The authors assume full responsibility for everything published in the article.

The authors guarantee the absence of competing and their own financial interests.

The manuscript was received by the editorial staff 15.12.2015. 


\section{MATERIALS AND METHODS}

The investigation has been carried out according to the «National General Principles for Animal Researches Ethics», which corresponds to the «European Convention for the Protection of Vertebrate Animals used for Experimental and Other Scientific Purposes» [8]. The animals have been kept in standard conditions of vivarium with natural light, ration and water supplying [9]. The modeling of $\mathrm{CP}$ has been fulfilled in rat's males (250-350 g of body mass) by cryo traumatizing of ventral part of prostate gland (vpPG) using cryo device Wartner (omega Pharma International, Belgium) (CP group). This model of CP has been accompanied with haemodynamic instability and inflammation developing that to some extent corresponds to mechanism of CP developing in men [10]. The control group of animals has been performed by falsely operated rats undergone the same manipulations as in the modeling, but without vpPG damaging.

For CP correction the NP composition have been chosen: Lanthanum Orthovanadate activated by Europium (NP $\mathrm{LaVo}_{4}: \mathrm{Eu}^{3+}$ ) in the rod shape (size $6-8^{\times} 50-56 \mathrm{~nm}$ ), Gadolinium Orthovanadate activated by Europium NP $\mathrm{GdVO}_{4}: \mathrm{Eu}^{3+}$ ) in spherical shape (size 1-2 nm) or in the grain shape (size: $8-10^{\times} 25 \mathrm{~nm}$ ) to which silver NP (NP Ag) was added (groups $\mathrm{CP}+$ nanorods, $\mathrm{CP}+$ spherical $\mathrm{NP}, \mathrm{CP}+$ grain shaped NP accordingly). The dose of substances were $0,3 \mathrm{mg} / \mathrm{kg}$ of body mass. All the research samples of NP have been synthesized and obtained in the Institute for Scintillation Materials of NAS of Ukraine according to the scientific cooperation agreement between SI «V. Danilevsky Institute for Endocrine Pathology Problems of the NAMS of Ukraine» and the SI «Institute for Scintillation Materials of NAS of Ukraine» (Department for nonstructural materials of the Institute for Scintillation
Materials, the head - Dr. Sc. (Phys.-Math, Maliukin Yu. V.).

«Prostatilen» $(0,5 \%)$ has been chosen to be the drug of comparison that is commonly used for treatment of chronic nonbacterial prostatitis and correction of men's infertility (group $\mathrm{CP}+\mathrm{Pr}$ ) [11]. The researched substances have been introduced from $15^{\text {th }}$ day after surgery during next 2 weeks in volume of $0,5 \mathrm{ml}$, into the upper part of rectum to a depth of 20-25 mm from anus using special non traumatic semirigid catheter.

The leukocytosis and changing of coefficients of prostate gland (PG) and seminal vesicles (SV) masses have been considered to be the criteria of pathology development. The quantity of leukocytes has been measured dynamically according to the common procedure [12]. Blood has been taken from rat's tail vein. The condition and masses of PG and SV have been determined after quick animal's decapitation, mass coefficients (the ratio of the organ's weight $(\mathrm{mm})$ to the animal weight $(\mathrm{g})$ ) have been calculated. The blood levels of general testosterone (Ts) have been determined using immunoferment test kit (firm "Chema», Russia) and immunoferment photometric analyzer Stat Fax 2100. The counting of sperm cells has been carried out in the suspension of appendix of the epididymis using Horiayev haemocytometer on common procedure, the concentration of morphologically normal cells was calculated $\mathrm{CN}$ $[13,14]$.

The figures obtained have been analyzed using Excel and Statistika 6,0 programs under Shapiro-Wilk test and $t$-Student test [15]. Data obtained were performed as the arithmetical mean $(\overline{\mathrm{X}})$ and its standard deviation $\left( \pm \mathrm{S}_{\overline{\mathrm{X}}}\right)$. The differences among groups have been considered as statistically significant at $\mathrm{P}<0,05$.

\section{RESULTS AND THEIR DISCUSSION}

Due to CP induced by cryo trauma of vpPG the disturbances of endocrine and spermatogenic functions have been observed [16].

It has been determined that modeling of $\mathrm{CP}$ has accompanied with increasing of leukocytes concentration. After two weeks of treating of $\mathrm{CP}$ by compositions contained NP with different form-factor the number of leukocytes has significantly decreased in all researched groups comparing with group of males with $\mathrm{CP}$ $(p<0,05)$ that may indicate declining of inflammation in the PG (fig. 1). The same results has been obtained after treatment of males with CP by referent cure «Prostatilen». 


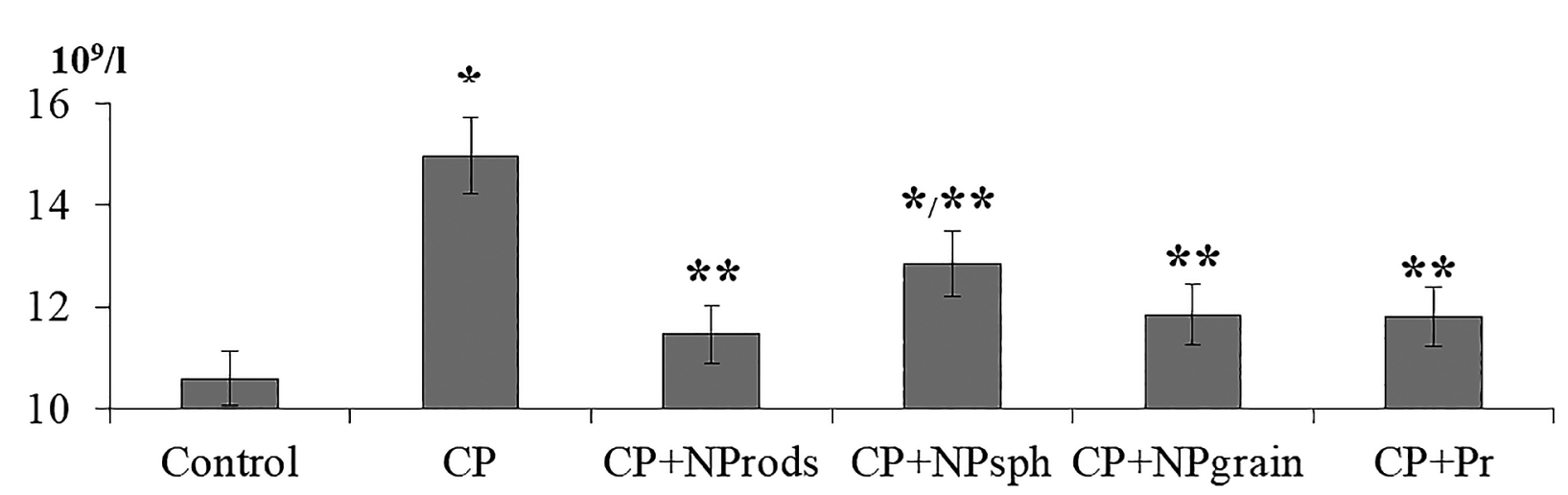

Fig. 1. The concentration of leukocytes in blood of rats with chronic prostatitis after treatment by nanoparticles with different form-factor.

* $\mathrm{P}<0,05$ comparing with control group;

$* * \mathrm{P}<0,05$ comparing with group of $\mathrm{CP}$.

According to author's data, nanoparticles of $\mathrm{GdVO}_{4}: \mathrm{Eu}^{3+}$ have demonstrated anti-inflammatory activity due to minimization of producing of active forms of oxygen at the inflammation sites. Combined with silver that has antibacterial effect, treatment has led to decreasing of general inflammation [3, 17].

It is known, that the haemodynamical disturbances caused by cryo trauma of PG, lead to inflammation development in the gland as well as in the rat's SV, which may be explained by sameness of trophic and functioning processes of these organs.

Owing to disturbances of drainage function of CP during inflammation the fluid is gaining in the lumen and the tension is increasing. These processes contribute to membrane ischemia and inflammation activating [18]. Thus, the increasing of $\mathrm{CV}$ fluid secretion (of $36 \%$ ), their mass coefficients (of $26 \%$ ) and $\mathrm{vpPG}$ (of $31 \%$ ) observed in males with $\mathrm{CP}$, may be considered as signs of inflammation of researched organs.

The treatment by NP with different formfactors, particularly by nanorods and spherical $\mathrm{NP}$, has caused the decreasing of vpPG mass coefficients (by $41 \%$ and $53 \%$ accordingly) and SV mass coefficients (by $35 \%$ and $30 \%$ accordingly, by lowering the mass of fluid) comparing with rats of $\mathrm{CP}$ group. The application of composition of grain-shaped NP and drug of comparison "Prostatilen» have no influenced the researched indices comparing with group of animals without treatment.

The functional disturbance of prostate gland due to inflammation leads to hormonal

Masses coefficients of sex organs of rats with chronic prostatitis treated by nanoparticles with different form-factor, $\overline{\mathrm{X}} \pm \mathrm{S}_{\overline{\mathrm{X}}}$

\begin{tabular}{|c|c|c|c|}
\hline \multirow{3}{*}{ Group } & \multicolumn{3}{|c|}{ Indices } \\
\hline & \multicolumn{2}{|c|}{ Mass coefficient } & \multirow{2}{*}{$\begin{array}{l}\text { Weight of seminal } \\
\text { vesicles fluid, mg }\end{array}$} \\
\hline & Seminal vesicles & $\begin{array}{c}\text { Ventral part } \\
\text { of prostate gland }\end{array}$ & \\
\hline Control (n = 13) & $3,4 \pm 0,2$ & $1,3 \pm 0,1$ & $610,5 \pm 35,0$ \\
\hline $\mathrm{CP}(\mathrm{n}=17)$ & $4,3 \pm 0,2^{*}$ & $1,7 \pm 0,1^{*}$ & $830,5 \pm 51,6^{*}$ \\
\hline $\mathrm{CP}+$ nanorods $(\mathrm{n}=9)$ & $2,8 \pm 0,3^{* *}$ & $1,0 \pm 0,1 * * * *$ & $443,0 \pm 81,6^{* *}$ \\
\hline $\mathrm{CP}+$ sph. NP $(\mathrm{n}=9)$ & $3,1 \pm 0,3^{* *}$ & $0,8 \pm 0,1 * / * *$ & $557,1 \pm 73,9^{* *}$ \\
\hline $\mathrm{CP}+$ gr. $\mathrm{NP}(\mathrm{n}=10)$ & $4,4 \pm 0,3^{*}$ & $1,6 \pm 0,1^{*}$ & $788,0 \pm 74,9^{*}$ \\
\hline $\mathrm{CP}+\operatorname{Pr}(\mathrm{n}=13)$ & $4,4 \pm 0,3^{*}$ & $1,6 \pm 0,1^{*}$ & $748,5 \pm 63,0$ \\
\hline
\end{tabular}

Notes:

* $\mathrm{P}<0,05$ comparing with control group;

** $\mathrm{P}<0,05$ comparing with group of $\mathrm{CP}$. 


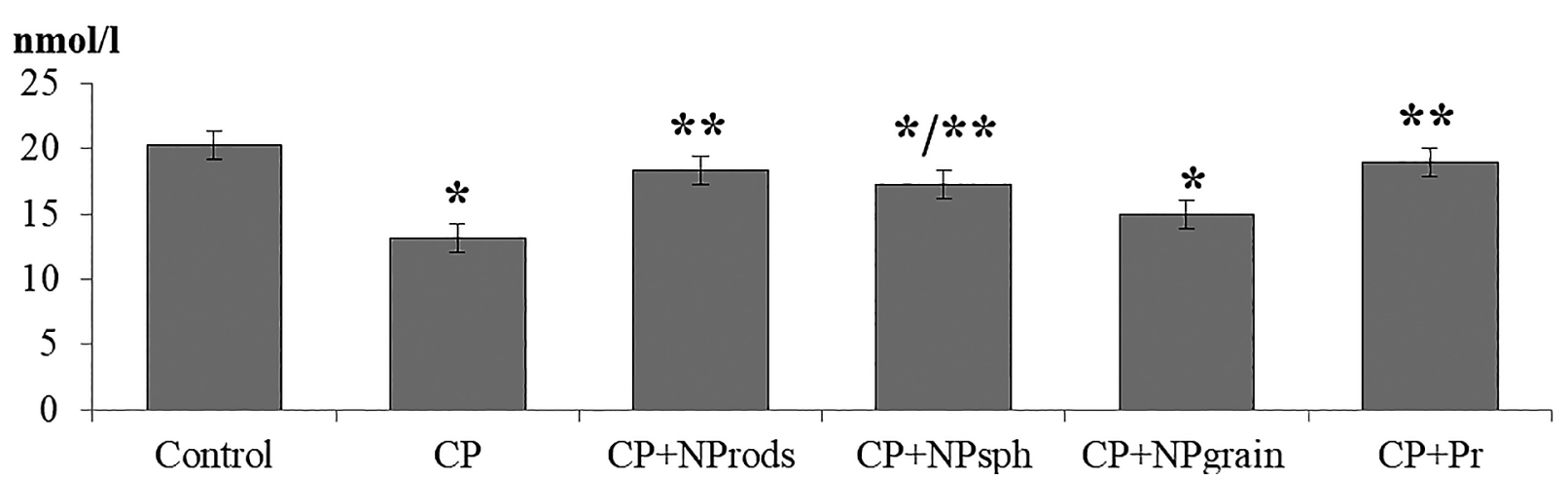

Fig. 2. Testosterone serum levels in rats with chronic prostatitis after treatment by nanoparticles with different form-factor.

* $\mathrm{P}<0,05$ comparing with control group;

$* * \mathrm{P}<0,05$ comparing with group of $\mathrm{CP}$.

and spermogram values changes (fig. 2 , tabl. 2 , group $\mathrm{CP}$ ).

Thus, testosterone serum blood level in rats with CP has declined by $35 \%$ comparing with Control group. The application of NP nanorods composition has led to the Ts levels normalization (up to $40 \%$ ), composition of spherical NP has increased Ts level by $31 \%$ comparing with CP group (see fig. 2). By application the drug of comparison "Prostatilen» Ts level has recovered up to intact group values, which corresponds to other authors' data [11].

The inflammation declining in the PG has facilitated the incretionary function of testis that has led to the substantial improvement of the spermogram's indices. Thus, the rats of $\mathrm{CP}+$ nanorods group have shown spermatozoons concentration increasing in 1,6 times, $\mathrm{C}_{\mathrm{N}}$ index - in 1,7 times more and sperms motility - in 1,4 times more than in rats of $\mathrm{CP}$ group $(p<0,05)$ whereas pathologically changed spermatozoons have decreased in 2,1 times comparing with CP group of rats $(p<0,05)$. Therefore, it can be argued that spermatogenic function has recovered according to the parameters listed above. The males of CP+ spherical NP group have demonstrated increased concentration of the morphologically normal spermatozoons by $49 \%$ and decreasing of number of abnormal sperm cells in more than 2 times

Spermogram indices of rats with chronic prostatitis

Table 2 after treating by nanoparticles with different form-factors, $\overline{\mathrm{X}} \pm \mathrm{S}_{\overline{\mathrm{X}}}$

\begin{tabular}{c|c|c|c|c}
\hline \multirow{2}{*}{ Group } & \multicolumn{4}{|c}{ Indices } \\
\cline { 2 - 5 } & $\begin{array}{c}\text { General } \\
\text { concentration, } \\
\mathbf{m l n} / \mathbf{m l}\end{array}$ & $\mathbf{C}_{\mathrm{N}}, \mathbf{m l n} / \mathbf{m l}$ & Motility, \% & $\begin{array}{c}\text { Pathological } \\
\text { form, } \%\end{array}$ \\
\hline Control (n= 7) & $68,4 \pm 5,2$ & $65,4 \pm 4,5$ & $74,6 \pm 4,4$ & $4,1 \pm 0,7$ \\
\hline $\mathrm{CP}(\mathrm{n}=16)$ & $40,3 \pm 3,9^{*}$ & $36,1 \pm 3,8^{*}$ & $45,9 \pm 3,5^{*}$ & $11,2 \pm 1,0^{*}$ \\
\hline $\begin{array}{c}\mathrm{CP}+\text { nanorods } \\
(\mathrm{n}=7)\end{array}$ & $63,0 \pm 6,7^{* *}$ & $60,0 \pm 6,9^{* *}$ & $63,1 \pm 6,6^{* *}$ & $5,4 \pm 1,1^{* *}$ \\
\hline $\begin{array}{c}\mathrm{CP}+\text { sph. NP } \\
(\mathrm{n}=9)\end{array}$ & $56,2 \pm 7,7$ & $53,7 \pm 7,6^{* *}$ & $53,3 \pm 5,1^{*}$ & $4,9 \pm 0,9^{* *}$ \\
\hline $\begin{array}{c}\mathrm{CP}+\text { gr. NP } \\
(\mathrm{n}=10)\end{array}$ & $49,5 \pm 5,0^{*}$ & $45,2 \pm 5,3^{*}$ & $74,8 \pm 3,0^{* *}$ & $8,3 \pm 1,1^{*}$ \\
\hline $\mathrm{CP}+\operatorname{Pr}(\mathrm{n}=12)$ & $52,3 \pm 3,4^{* * * *}$ & $49,1 \pm 3,3^{* * * *}$ & $66,6 \pm 4,6$ & $6,4 \pm 0,9^{* *}$ \\
\hline
\end{tabular}

Notes:

* $\mathrm{P}<0,05$ comparing with control group;

** $\mathrm{P}<0,05$ comparing with group of $\mathrm{CP}$;

$\mathrm{CN}$ - the concentration of morphologically normal sperms. 
comparing with $\mathrm{Cp}$ group data. The increasing of percentage of motile sperms (oscillatory movement) by $63 \%$ has been detected in $\mathrm{CP}+$ grain shaped NP group while other indices had no changes comparing with the same one in rats with $\mathrm{CP}$. The introduction of «Prostatilen» has led to the improvement of sperm indices comparing with CP group (see table 2).

Therefore, data obtained have shown that composition of nanorods $\left(\mathrm{LaVo}_{4}: \mathrm{Eu}^{3+}+\mathrm{Ag}\right)$ was more effective in $\mathrm{CP}$ consequences tackling. It might occurre due to interaction among the most part of receptors on the cells surface with nanorods long spindles that facilitates their absorption [19]. Moreover, it has been observed that nanorods may reach nucleuses of tumor, whereas other nanoparticles (specifically spheres) have been detected only on the tumor surface that confirms the distinctiveness of nanorods [20]. The results of our investigation have shown that nanoparticles of $\mathrm{La}_{2} \mathrm{O}_{3}$ have reduced the disturbances of spermatogenesis in rats [7].

\section{CONCLUSIONS}

1. Due to chronic prostatitis induced by cryo trauma of ventral part of the prostate gland the disturbances of the endocrine and spermatogenic functions of rats testicles are observed.

2. The using of NP composition based on the orthovanadates of rare-earth elements and silver NP as the pathology treatment decline the consequences of the chronic prostatitis and have effectiveness at the level of the referent drug "Prostatilen» which is widely used for medication of the chronic nonbacterial prostatitis and males infertility.

3. The using of composition of $\mathrm{NP}_{\mathrm{LaVo}_{4}}: \mathrm{Eu}^{3+}+$ $\mathrm{Ag}$ (nanorods) has marked capacity to inhibit systemic inflammation and to reduce the consequences of cryo trauma of prostate gland via restoring masses coefficient of epididymis and testosterone level and improving rats spermogram. For spermogram indicators, the effectiveness of these NP does not concede, but even exceeds on some parameters the drug of comparison «Prostatilen».

4. In general, the using of $\mathrm{NP} \mathrm{GdVO}_{4}: \mathrm{Eu}^{3+}+\mathrm{Ag}$ in the spherical shape has positively influenced the consequences of chronic prostatitis caused by cryo trauma of ventral part of prostate gland, although the effectiveness was less distinct.

5. The using of the NP based on the rare-earth elements oxides has demonstrated prostate protective effect. The efficacy of the NP relative to the experimental prostatitis depends on composition and their form-factor.

\section{REFERENCES}

1. Litvinets EA, Trisch VI. Zdorov'e Muzhchiny 2017; 2(61): 53-57.

2. Tutchenko OA, Burka VS, Samilyk OV, et al. Reproduktpuna endokrinologíya 2020; 55: 21-28.

3. Zeynalov OA, Kombarova SP, Bagrov DV, et al. Rev Clin Pharmacol Drug The 2016; 14(4): 42-51. doi: 10.17816/ RCF14442-51.

4. Boles MA, Engel M, Talapin DV. Chem Rev 2016; 116(18): 11220-11289. doi: 10.1021/acs.chemrev.6b00196.

5. Kinnear C, Moore ThL, Rodriguez-Lorenzo L, et al. Chem Rev 2017; 117(17): 11476-11521.doi: https://doi. org/10.1021/acs.chemrev.7b00194.

6. Korenyeva YeM, Karpenko NO, Smolyenko NP, et al. Probl Endokryn Patolohiyi 2016; 1: 48-56.

7. Lu Y, Li Q, Bai D, et al. Int J Nanomedicine 2020; 15: 3415-3431.

8. Endokrynolohiya 2003; 8(1): 142-145.

9. Zapadnjuk IP, Zapadnjuk VI, Zaharija EA, et al. Laboratornye zhivotnye. Razvedenie, soderzhanie, ispol'zovanie v jeksperimente, Kiev, 1983: 383 p.
10. Zaychenko HV, Andriyanenkov OV, Soldatova SO, et al. Informatsiynyy lyst pro novovvedennya $\mathrm{v}$ sferi okhorony zdorovya, Kiev, 2013: 28.

11. Zhukov OB, Evdokimov VV, Bragina EE. Andrologija I genital'naja hirurgija 2017; 18(1): 3-9. doi: 10.17650/ 2070-9781-2017-18-102-108.

12. Men'shikov VV, Delektorskaya LN, Zolotnitskaya RP, et al. Laboratory research methods in clinic: Reference book, Moskva, 1987: 368 p.

13. Petrishchev VS, Shchelochkov AM. Problemy reproduktsii 2002; 3: 87-91.

14. Karpenko NO, Talko VV, Omelchuk ST, Lapta SS. Kiev, 2011: 23 p.

15. Atramentova LO, Utjevs'ka OM. Statystychni metody v biologii': pidruchnyk, Harkiv, 2007: 288 p.

16. Brechka NM. Ukr zhurn medytsyny, biolohiyi ta sportu 2019; 4(20): 237-243.

17. Kavok NS, Averchenko KA, Klochkov VK. Eur Phys J E Soft Matter 2014; 37(12): 127. 
18. Al'-Shukri SKH, Gorbachev AG, Knyaz'kin IV, et al. Urologicheskiye vedomosti 2013; 2: 24-30.

19. Dai L. Department of Environmental, Social and Spatial Change (ENSPAC), Roskilde University, 2013: 153 p.
20. Black KCL, Wang Y, Luehmann HP, et al. ACS NANO 2014; 8(5): 4385-4394.

\author{
THE CORRECTION OF THE CONSEQUENCES \\ OF THE EXPERIMENTAL PROSTATITIS BY NANOPARTICLES \\ OF ORTHOVANADATES OF THE RARE-EARTH ELEMENTS \\ Chystiakova E. Ye. ${ }^{1}$, Smolienko N. P. ${ }^{1}$, Bielkina I. O. ${ }^{1}$, Velychko N. F. ${ }^{1}$, \\ Korenieva Ye. M. ${ }^{1}$, Boiko M. O. ${ }^{1}$, Kustova S. P. ${ }^{1}$, Klochkov V. K. ${ }^{2}$, \\ Bondarenko V. O. ${ }^{1}$, Karpenko N. O. ${ }^{1}$ \\ ${ }^{1}$ SI «V. Danilevsky Institute for Endocrine Pathology Problems of the NAMS of Ukraine»; \\ Kharkiv, Ukraine; \\ ${ }^{2}$ SI «Institute for Scintillation Materials of NAS of Ukraine, Kharkiv, Ukraine»; \\ reproduk@ipep.com.ua
}

The management of patients with chronic prostatitis (CP) remains the difficult medical and social problem that makes the elaboration of new prostate protectors actual. The purpose of the work: to ascertain the effectiveness of nanoparticles' of rare-earth elements with different form-factors correction of the pathological seminal's endocrine and spermatogenic function disturbances caused by chronic experimental prostatitis.

The modeling of CP in mature rats' males has been fulfilled using Wartner device by cryo trauma of the prostate gland making. The compositions of nanoparticles (NP) of rare-earth metals $\left(\mathrm{LaVO}_{4}\right.$ or $\left.\mathrm{GdVO}_{4}\right)$ activated by Europium, with NP Ag added, in shape of rods, spheres and grains have been chosen for CP correction. The dose was $0,3 \mathrm{mg} / \mathrm{kg}$ of body weight. The drug of comparison was $0,5 \%$ «Prostatilen». The researched substances have been rectally introduced in volume of $0,5 \mathrm{ml}$ from $15^{\text {th }}$ after surgery during next two weeks. The number of leukocytes in blood, condition and masses of the prostate gland and seminal vesicles, the concentration of the general testosterone and spermatogenesis indices have been determined.

It has been determined that using of NP composition based on the oxides of rare-earth elements and NP $\mathrm{Ag}$ (nanorods) for pathology correction has declined consequences of CP: the general inflammation has been substantially inhibited, mass coefficients of the epididymis and testosterone level have been recovered and spermatogenesis have been improved. For some spermogram indices, the activity of these NP does not concede, but even exceeds the activity of drug of comparison. The using of $\mathrm{NP} \mathrm{GdVO}_{4}: \mathrm{Eu}^{3+}+\mathrm{Ag}$ in the spherical shape has positively influenced the correction of chronic prostatitis, although the effectiveness was less distinct.

Thus, the composition of nanoparticles $\mathrm{LaVO}_{4}: \mathrm{Eu}^{3+}+\mathrm{Ag}$ in the form of rods has a positive effect on the sexual function of rats with chronic prostatitis compared with the effect of nanoparticles $\mathrm{GdVO}_{4}: \mathrm{Eu}^{3+}+\mathrm{Ag}$ in the form of spheres or grains.

Key words: experimental chronic prostatitis, nanoparticles of silver and rare-earth metals, spermogram, testosterone. 


\section{КОРЕКЦІЯ НАСЛІДКІВ ХРОНІЧНОГО \\ ЕКСПЕРИМЕНТАЛЬНОГО ПРОСТАТИТУ НАНОЧАСТИНКАМИ ОРТОВАНАДАТІВ РІДКІСНОЗЕМЕЛЬНИХ ЕЛЕМЕНТІВ \\ Чистякова Е. Є. ${ }^{1}$, Смоленко Н. П. ${ }^{1}$ Белкіна I. О. ${ }^{1}$, Величко Н. Ф. ${ }^{1}$, Коренева С. М. ${ }^{1}$, Бойко М. О. ${ }^{1}$, Кустова С. П. ${ }^{1}$, Клочков В. К. ${ }^{2}$, Бондаренко В. O. ${ }^{1}$ Карпенко Н. О. ${ }^{1}$ \\ ${ }^{1}$ ДУ «Інститут проблем ендокринної патологї̈ ім. В. Я. Данилевського НАМН України», м. Харків, Україна; \\ ${ }^{2}$ ДУ «Інститут сиинтиляційних матеріалів НАН Украӥни», м. Харків, Украӥна reproduk@ipep.com.ua}

Лікування хворих на хронічний простатит (ХП) залишається складною медичною та соціальною проблемою, що обумовлюе актуальність створення нових простатопротекторів. Мета роботи: визначення впливу наночастинок рідкісноземельних елементів із різним форм-фрактором щодо корекції патологічного стану ендокринної та сперматогеної функції сім'яників внаслідок хронічного експериментального простатиту.

Моделювали ХП у статевозрілих самців щурів шляхом кріотравмування передміхурової залози за допомогою кріопристрою Wartner. Контрольну групу склали хибно оперовані щури. Для корекції ХП було обрано композиції наночастинок (НЧ) рідкісноземельних металів $\left(\mathrm{LaVO}_{4}\right.$ або GdVO $)$, активованих европіем, до яких було приеднано НЧ Ag, у формі стрижнів, сфер або зерен. Доза складала 0,3 мг/кг маси тіла. Препарат порівняння - 0,5 \% Простатилен. Досліджувані сполуки уводили ректально з 15-ї доби після операцій протягом 2-х тижнів в об’емі 0,5 мл. Визначали кількість лейкоцитів у периферичній крові, стан та масу простати та сім'яних пухирців, концентрацію загального тестостерону, показники сперматогенезу.

Встановлено, що використання композиції НЧ на основі оксидів рідкісноземельних елементів та НЧ срібла (у формі стрижнів) для корекції патологічного стану зменшувало наслідки ХП: виразно гальмувало розвиток системного запального процесу, відновлювало масові коефіцієнти додаткових статевих залоз, рівень чоловічого статевого гормону та покращувало сперматогенез. За деякими показниками спермограми дія цих НЧ не поступається, а, навіть, перевищує дію препарату порівняння. Застосування $\mathrm{HЧ} \mathrm{GdVO}_{4}: \mathrm{Eu}^{3+}+\mathrm{Ag}$ у формі сфер в цілому мало позитивний вплив щодо корекції ХП, але мало менш виразний ефект.

Таким чином, композиція наночастинок $\mathrm{LaVO}_{4}: \mathrm{Eu}^{3+}+\mathrm{Ag}$ у формі стрижнів має позитивний ефект для статевої фрункії щурів з хронічним простатитом порівняно 3 впливом наночастинок $\mathrm{GdVO}_{4}: \mathrm{Eu}^{3+}+\mathrm{Ag}$ у форормі сфрер або зерен.

Ключові слова: експериментальний хронічний простатит, наночастинки рідкісноземельних металів та срібла, спермограма, тестостерон. 